\title{
Association between obesity and perceived halitosis in Korean adolescents
}

\author{
Seon-Ju Sim* \\ Department of Dental Hygiene, Baekseok University, Cheonan 31065, Republic of Korea \\ (Received Jul 17, 2017; Revised version received [1] Oct 14, 2017 [2] Nov 23, 2017; Accepted Nov 24, 2017)
}

\begin{abstract}
Adolescent obesity is a growing problem, which is related to serious medical diseases, including poor oral health. Halitosis is an important part of oral health. Therefore, the present study aimed to examine the association between perceived halitosis and obesity in Korean adolescents. The present study used data from the 2015 Korea Youth Risk Behavior Web-based Survey in analyzing 68,043 Korean adolescents aged 12-18. The dependent variables, perceived halitosis, and socioeconomic variables, health-related variables, and oral health-related variables, were collected by using self-administered questionnaires. A multiple logistic regression analysis was used to evaluate the association between obesity and perceived halitosis while controlling for school type, city scale, economic status, education levels of parents, academic achievement, stress, physical activity, drinking, smoking, taking frequencies of fast foods, soda, and fruits, tooth brushing frequency, and interdental cleaning. In the descriptive analysis, adolescents with a low socioeconomic status were more likely to be obese and perceived higher halitosis. In addition, perceived halitosis was associated with low physical activity, high stress, and low tooth brushing frequency. After adjusting for confounders, there was a significant association between obesity and perceived halitosis [odds ratio (95\% Confidence Interval (CI)) : 1.22 (1.06-1.42)]. Odds ratio (OR) of girls was 1.60 (95\% CI : 1.17-2.20) and OR of boys was 1.15 (95\% CI : 0.98-1.35). This study demonstrates that obesity is closely associated with perceived halitosis in Korean adolescents. Therefore, intervention programs are required to prevent obesity and malodors for adolescents on a national scale.
\end{abstract}

KEY WORDS: Adolescents, Halitosis, Obesity, Socioeconomic status

\section{서 론}

전 세계적으로 청소년기의 비만은 빠른 속도로 증가하 고 있으며 청소년기의 비만은 성인기 비만으로 이행될 가 능성이 높아 중요한 관심사 중의 하나가 되고 있다[1]. 한 국에서도 청소년기의 비만율은 빠른 증가추세를 보여 청 소년기의 비만은 중요한 건강문제로 대두되고 있다[2]. 비 만은 단순한 체형상의 문제를 넘어 치료가 필요한 만성질 환으로 구분되고 있으며[3] 비만의 원인으로는 여러 사회 학적 변수, 건강관리 행위, 심리적인 원인뿐만 아니라 가족, 학교, 지역사회 등의 환경적 원인이 복합적으로 작용하고 있다고 보고되고 있으며[4], 잘 관리되지 않은 비만은 심혈 관 질환, 당뇨, 고지혈증, 요통, 지방간, 사망뿐만 아니라 정

\footnotetext{
*Corresponding author: Seon-Ju Sim

Department of Dental Hygiene, Baekseok University, 76 Munam-ro, Dongnam-gu, Cheonan-si, Chungcheongnam-do 31065, Republic of Korea Tel.: +82-41-550-2311, Fax: +82-41-550-2829

E-mail: vision1991@daum.net
}

신적 질환을 야기시킬 수 있다고 보고되었다[5-7].

구취는 생리적인 원인 혹은 여러 병적 원인으로 입안에 서 발생하는 불쾌한 냄새를 말하며, 구강건강 및 전신건강 의 지표로서 뿐만 아니라 사회생활 및 정신건강에 중요한 영향을 미치는 요인으로 대두되고 있다. 구취의 구강 내 원인으로는 설태, 치주질환, 치아우식증, 불량한 구강위생 상태와 불량보철물, 타액분비량, 타액선 질환, 구강암 등이 있으며, 구강 외 원인으로는 이비인후과 질환, 소화기계 및 호흡기계 질환 등으로 알려져 있다[8]. 한국인의 구취 실태에 대한 역학조사에서는 구취치료가 필요한 사람은 $25.9 \%$ 이었고, 여자에 비해 남자가, 연령이 증가할수록 구 취가 증가하는 것으로 나타났다[9]. 우리나라 청소년기는 과중한 시험공부에 시달리어 구강관리에 소홀하기 쉽고 당류를 많이 섭취하게 되어 구강건강이 악화되고 있는 실 정이다[10]. 신장과 체중이 증가하는 청소년기는 일생을 통하여 건강유지의 기초를 만들어야 하는 중요한 시기이 므로 건강한 생활을 위한 습관이 중요하다[11]. 비만과 구 강질환 모두 학령기부터 시작하여 비교적 경험률이 높은 질환으로서 비만과 구강질환은 두 질환의 위험요소들이 
서로 연관되어 있다고 보고되었다[12,13]. 비만은 치아우 식증과 치주염과 연관되었을 뿐만 아니라 $[13,14]$ 최근에는 구취와의 연관성도 보고되고 있다[15]. Hilgers 등[14]은 811 세 아동에서 체질량지수가 증가함에 따라 영구치구치부 의 인접면 치아우식증 발생이 증가한다고 보고하였다.

비만은 전신건강의 위험요소일 뿐만 아니라 구강건강에 대한 위험요소로서 작용하여 관리의 중요성이 부각되고 있다. 그러나 치아우식증 및 치주염과 비만에 관한 연구들 은 보고되고 있지만[13,14] 구취와 비만에 대한 연구는 부 족한 실정이다. 따라서 본 연구에서는 우리나라 청소년을 대상으로 청소년들의 주관적 구취여부와 비만율과의 상관 관계를 파악하여 구취 예방 및 비만 예방을 위한 기초 자 료로 활용하고자 한다.

\section{대상 및 방법}

\section{연구대상}

본 연구의 대상은 보건복지부의 질병관리본부 주관으로 시행한 2015년 청소년건강행태온라인조사의 자료를 이용 하였다[16]. 전체 조사대상은 2015년 9월을 기준으로 전국 중학교 1학년부터 고등학교 3 학년까지의 재학생을 모집단 으로 하였으며 대상자는 층화집락확률추출방법에 의해 선 정되었으며 조사를 완료한 학생은 68,043 명으로 참여율은 $96.7 \%$ 이었다.

\section{자료수집 및 설문지 구성}

청소년건강행태온라인조사는 인터넷이 가능한 학교 컴 퓨터실에서 ‘익명성 자기기입식 온라인조사'로 이루어졌 다. 중·고등학교 재학생에서 추출된 전국 단위 표본인구로 시도·도시규모별 집락으로 할당된 표본 배분결과를 기준 으로 집락별 할당된 표본 수만큼 계통추출법으로 800 개 표본학교가 선정되었다. 표본학급은 표본학교에서 학년별 로 1 개 학급을 선정하였으며, 표본학생은 표본학급으로 선 정된 학급의 학생전원이 선정되었다. 다만, 장기결석, 특수 아동 및 문자해독 장애 학생은 제외되었다. 본 연구의 설 문지의 구성은 조사 대상자의 사회경제적 특성, 건강 관련 행위, 구강보건행위, 식이 섭취 행태로 이루어졌다. 일반적 인 특성은 학년, 거주지역, 경제상태, 부모님 최종학력, 학 업성적, 음주여부, 흡연여부, 신체활동 여부, 스트레스 정 도 등으로 구분하였으며, 구강보건행태로는 하루 잇솔질 횟수와 점심 식사 후 잇솔질 여부, 그리고 치간 세정 여부 로 구분하였고 식이 섭취행태로는 패스트푸드 섭취 빈도, 소다 음료 식음 빈도, 그리고 과일 섭취 빈도로 구분하였 다. 설문지의 변수들을 다시 이분변수화 하였는데 학년을 중학교와 고등학교로 나누었고, 경제상태는 상(상, 중상)과
하(중, 중하위, 하위)로 나누었으며, 학업성적도 상(상, 중 상위)과 하(중, 중하, 하위)로 나누었고, 부모 학력은 전문 대학졸업이상과 미만으로 나누었으며, 신체활동여부는 하 루60분 주 5일 이상 신체활동 이상과 미만으로 나누었고, 스트레스 정도는 높음(대단히 많이 느낀다, 많이 느낀다) 과 낮음(조금 느낀다, 별로 느끼지 않는다, 전혀 느끼지 않 는다)으로 나누었다. 동시에, 식이 습관으로는 패스트푸드 와 소다음료 식음 빈도수는 높음(일주일에 3회 이상 식음 한다)과 낮음(일주일에 3회 미만 식음한다)으로 나누었고, 과일섭취 빈도수는 높음(일주일간 5 회이상이다)과 낮음(일 주일간 5회 미만이다)으로 나누었으며 하루 잇솔질 횟수 는 3회 이상과 3 회 미만으로 나누었고, 점심식사 후 잇솔 질 시행 여부는 거의 시행한다(항상 했다, 대부분 했다)와 거의 시행하지 않는다(가끔 했다, 안했다)로 나누었으며, 구강관리용품을 이용한 치간세정을 한다와 하지 않는다로 나누었다. 과체중과 비만의 정의는 2007년 소아청소년 성 장도표[17]를 이용하여 연령별 체질량지수에 따라 저체중 , 정상, 과체중, 비만으로 분류하였다. 종속변수로는 구취 자각에 관한 설문은 “지난 일 년 동안, 불쾌한 입 냄새가 나는 증상을 경험한 적이 있습니까?”에 대한 문항으로 구 성되었으며 “지난 일 년 동안 경험 한 적이 있다.”, “지난 일 년 동안 경험한 적이 없다.”를 구취자각 유무로 나누었 다.

\section{자료분석}

통계 프로그램은 SPSS version 20.0 (SPSS Inc., Chicago, $\mathrm{IL}, \mathrm{USA}$ )를 이용하였다. 분석은 남녀 간에 구취 관련요인 의 특성이 다르다고 생각하여 남녀를 구분하여 분석하였 다. 분석 방법은 복합표본교차분석을 실시하여 성별에 따 른 비만율과 사회경제학적 변수 및 전신건강요인, 구강건 강행위 및 음식 섭취 행태를 분석하였으며 구취자각률도 사회경제학적 변수 및 전신건강요인, 구강건강행위 및 식 이 섭취 행태와 비교 분석하였다. 그리고 비만과 구강건강 상태와의 연관성을 조사하기 위해 구취 및 비만과 관련된 관련요인을 보정한 후 다중 로지스틱 회귀분석을 이용하 여 교차비를 구하였다. 제시된 결과는 조사에 참여한 표본 이 우리나라 청소년을 대표하도록 가중치를 반영하였다. 빈도는 가중치를 부여하지 않은 값으로 제시하였고, 백분 율과 교차비, 신뢰구간은 가중치를 부여한 값으로 제시하 였다.

\section{결 과}

1. 성별에 따른 사회경제학적 변수와 건강요인과 비만율 (Table 1) 
Table 1. Obesity according to sociodemographic status and lifestyles by sex

\begin{tabular}{|c|c|c|c|c|c|c|c|c|c|c|}
\hline \multirow[b]{2}{*}{ Variables } & \multicolumn{5}{|c|}{ Boys, n (\%) } & \multicolumn{5}{|c|}{ Girls, n (\%) } \\
\hline & $\begin{array}{l}\text { Under } \\
\text { weight }\end{array}$ & Normal & $\begin{array}{l}\text { Over } \\
\text { weight }\end{array}$ & Obese & -value & $\begin{array}{l}\text { Under } \\
\text { weight }\end{array}$ & Normal & $\begin{array}{l}\text { Over } \\
\text { weight }\end{array}$ & Obese & p-value \\
\hline Total & $2088(6.2)$ & $26424(77.4)$ & $822(2.2)$ & $4818(14.2)$ & 01 & $1663(5.3)$ & $25496(80.4)$ & 2391(7.1) & $2366(7.2)$ & 0.01 \\
\hline \multicolumn{11}{|l|}{ School type } \\
\hline Middle school & $1013(6.0)$ & $13646(78.8)$ & $756(4.2)$ & $1954(10.9)$ & \multirow[t]{2}{*}{$<0.01$} & $719(4.6)$ & $12988(82.1)$ & $1419(8.3)$ & $879(5.1)$ & \multirow[t]{2}{*}{$<0.01$} \\
\hline High school & $1075(6.4)$ & $12778(76.1)$ & $66(0.4)$ & $1864(17.1)$ & & $944(5.9)$ & $12508(78.8)$ & $972(6.2)$ & $1487(9.1)$ & \\
\hline \multicolumn{11}{|l|}{ City scale } \\
\hline Big city & $0.77(6.2)$ & 13393(77.3) & $413(2.1)$ & $2407(14.3)$ & \multirow[t]{3}{*}{$<0.01$} & $916(5.5)$ & 13533(81.3) & $1165(6.7)$ & $1080(6.5)$ & \multirow[t]{3}{*}{$<0.01$} \\
\hline Middle city & $947(6.4)$ & $11810(77.5)$ & $365(2.2)$ & $2175(13.9)$ & & $683(5.2)$ & $10658(79.5)$ & $1073(7.5)$ & $1132(7.8)$ & \\
\hline Town & $64(4.3)$ & $1221(77.4)$ & $44(2.8)$ & $236(15.5)$ & & $64(3.8)$ & $1305(78.1)$ & $153(8.5)$ & $154(9.6)$ & \\
\hline \multicolumn{11}{|c|}{ Perceived household economic status } \\
\hline High & $728(5.6)$ & 10244(77.9) & $369(2.8)$ & $1786(13.7)$ & \multirow[t]{2}{*}{$<0.01$} & $570(5.3)$ & $8804(82.9)$ & $718(6.3)$ & $615(5.5)$ & \multirow[t]{2}{*}{$<0.01$} \\
\hline Low & $1360(6.6)$ & $16180(77.1)$ & $426(1.8)$ & $3032(14.5)$ & & $1093(5.2)$ & $16692(79.1)$ & $1673(7.6)$ & $1751(8.1)$ & \\
\hline \multicolumn{11}{|c|}{ Father's education (years) } \\
\hline$\geq 12$ & $994(6.1)$ & 13086(78.9) & $380(2.1)$ & $2138(12.9)$ & \multirow[t]{2}{*}{$<0.01$} & $851(5.6)$ & $12647(82.5)$ & $1000(6.3)$ & $881(5.6)$ & \multirow[t]{2}{*}{$<0.01$} \\
\hline $9-12$ & $1094(6.4)$ & 13338(75.9) & $442(0.1)$ & $2680(15.5)$ & & $812(4.9)$ & $12849(78.3)$ & $1391(8.0)$ & $1485(8.8)$ & \\
\hline \multicolumn{11}{|c|}{ Mother's education (years) } \\
\hline$>12$ & $867(6.0)$ & $11618(79.0)$ & $351(2.2)$ & $186(12.8)$ & \multirow[t]{2}{*}{$<0.01$} & $726(5.4)$ & $11124(82.7)$ & $900(6.4)$ & $745(5.5)$ & \multirow[t]{2}{*}{$<0.01$} \\
\hline $9-12$ & $1221(6.4)$ & $14806(76.2)$ & $471(2.2)$ & $2957(15.3)$ & & $937(5.1)$ & $14372(78.6)$ & 1491(7.7) & $1621(8.6)$ & \\
\hline \multicolumn{11}{|c|}{ Subjective academic achievement } \\
\hline High & $767(6.0)$ & 10294(79.2) & $318(2.3)$ & $1632(12.6)$ & \multirow[t]{2}{*}{$<0.01$} & $603(5.1)$ & $9934(83.0)$ & $808(6.3)$ & $673(5.6)$ & \multirow[t]{2}{*}{$<0.01$} \\
\hline Low & $1321(6.4)$ & $16130(76.3)$ & $504(2.1)$ & $3186(15.0)$ & & $1060(5.4)$ & $15562(78.8)$ & $1583(7.7)$ & $1693(8.2)$ & \\
\hline \multicolumn{11}{|l|}{ Drinking } \\
\hline No & $488(5.6)$ & $6777(77.0)$ & $174(1.7)$ & $1373(15.7)$ & \multirow[t]{2}{*}{$<0.05$} & $313(4.6)$ & $5454(79.4)$ & $521(7.3)$ & $616(8.8)$ & \multirow[t]{2}{*}{0.089} \\
\hline Yes & $361(5.7)$ & $5098(77.8)$ & $73(1.1)$ & $1018(15.5)$ & & $226(5.6)$ & $3149(79.6)$ & $275(6.4)$ & $342(8.4)$ & \\
\hline \multicolumn{11}{|l|}{ Smoking } \\
\hline No & $218(4.9)$ & $3538(78.3)$ & $67(1.4)$ & $703(15.4)$ & \multirow[t]{2}{*}{$<0.01$} & $86(4.5)$ & 1372(77.3) & $149(7.7)$ & $193(10.5)$ & \multirow[t]{2}{*}{$<0.01$} \\
\hline Yes & $248(6.5)$ & $3034(78.4)$ & $36(0.8)$ & $560(14.3)$ & & $62(6.8)$ & $711(79.8)$ & $64(6.7)$ & $64(6.7)$ & \\
\hline Phys & & & & & & & & & & \\
\hline$<5$ times/week & $1778(6.7)$ & $20564(76.6)$ & $664(2.2)$ & $3907(14.5)$ & $<0.01$ & $1551(5.3)$ & $23604(80.5)$ & $2188(7.1)$ & $2176(7.1)$ & 0.098 \\
\hline$\geq 5$ times/week & $310(4.5)$ & $5860(80.6)$ & $158(2.1)$ & 911(12.9) & & $112(4.5)$ & 1892(79.4) & $203(8.1)$ & $190(8.1)$ & \\
\hline Stress & & & & & & & & & & \\
\hline High & $642(6.7)$ & $7470(75.5)$ & $232(2.2)$ & $1568(15.7)$ & $<0.01$ & $682(5.2)$ & $10298(78.8)$ & $1074(7.7)$ & $1138(8.3)$ & $<0.01$ \\
\hline Low & $1446(6.1)$ & $18954(78.2)$ & $590(2.2)$ & $3250(13.5)$ & & $981(5.3)$ & $15198(81.5)$ & $1317(6.8)$ & $1228(6.5)$ & \\
\hline
\end{tabular}

Values are presented as unweighted numbers (weighted \%).

P-value obtained from chi-square statistics.

남학생의 경우 전체 대상자의 $2.2 \%$ 학생이 과체중으로 $14.2 \%$ 학생이 비만으로 조사되었으며, 여학생의 경우 $7.1 \%$ 학생이 과체중으로 $7.2 \%$ 학생이 비만으로 조사되었 다. 남학생의 경우 중학생의 $4.2 \%$ 에서 과체중으로 $10.9 \%$ 학생이 비만으로 조사되었으며, 고등학생의 경우 $0.4 \%$ 학 생이 과체중으로 $17.1 \%$ 학생이 비만으로 조사되었고, 여 학생의 경우 중학생의 경우 $8.3 \%$ 학생이 과체중으로 $5.1 \%$ 학생이 비만으로 조사되었으며, 고등학생의 경우 $6.2 \%$ 학 생이 과체중으로 $9.1 \%$ 학생이 비만으로 조사되었다. 도시 규모에서는 남학생의 경우 군지역 거주학생의 $15.5 \%$ 에서 비만으로 조사되었고 여학생의 경우 군지역 거주자의 $9.6 \%$ 에서 비만으로 조사되었다. 남학생과 여학생의 경우
가계 경제수준이 낮을수록, 부모의 교육수준이 낮을수록, 주 관적 학업성취도가 낮을수록, 그리고 학업성취도가 낮을수 록 비만율이 높게 조사되었다. 그리고 신체활동이 적을수록, 스트레스 정도가 높을수록 비만율이 높게 조사되었다.

2. 성별에 따른 구강건강행위와 음식섭취행태에 따른 비 만율(Table 2)

남학생의 경우 일일 잇솔질 횟수가 3 회 미만이라고 응 답한 학생의 $2.3 \%$ 에서 과체중으로 $15.1 \%$ 에서 비만으로 조사되었으며, 여학생의 경우 일일 잇솔질 횟수가 3 회 미 만이라고 응답한 학생의 $8.3 \%$ 에서 과체중으로 $8.3 \%$ 에서 비만으로 조사되었다. 그리고 점심 후 잇솔질을 하지 않을 수록, 치간세정을 하지 않을수록, 과일섭취량이 적을수록 
Table 2. Obesity according to oral health behaviors and food intake styles by sex

\begin{tabular}{|c|c|c|c|c|c|c|c|c|c|c|}
\hline \multirow[b]{2}{*}{ Variables } & \multicolumn{5}{|c|}{ Boys, n (\%) } & \multicolumn{5}{|c|}{ Girls, n (\%) } \\
\hline & $\begin{array}{l}\text { Under } \\
\text { weight }\end{array}$ & Normal & $\begin{array}{l}\text { Over } \\
\text { weight }\end{array}$ & Obese & -value & $\begin{array}{l}\text { Under } \\
\text { weight }\end{array}$ & Normal & $\begin{array}{c}\text { Over } \\
\text { weight }\end{array}$ & Obese & p-value \\
\hline \multicolumn{11}{|c|}{ Tooth brushing frequency } \\
\hline$<3$ times/day & $1179(6.3)$ & $14623(76.2)$ & $498(2.3)$ & $2908(15.1)$ & $<0.01$ & $653(4.7)$ & $10452(78.7)$ & $1170(8.3)$ & $1147(8.3)$ & $<0.01$ \\
\hline$\geq 3$ times/day & $909(6.1)$ & $11801(78.9)$ & $324(2.0)$ & $1910(13.0)$ & & $1010(5.7)$ & $15044(81.7)$ & $1221(6.3)$ & $1219(6.4)$ & \\
\hline \multicolumn{11}{|c|}{ Toothbrushing after lunch } \\
\hline Mostly done & $565(5.9)$ & $7715(79.3)$ & $148(1.3)$ & $1276(13.4)$ & $<0.01$ & $884(5.4)$ & $13708(80.8)$ & $1154(6.5)$ & $1267(7.3)$ & $<0.01$ \\
\hline Rare done & $1523(6.4)$ & $18709(76.7)$ & $674(2.5)$ & $3542(14.5)$ & & $779(5.1)$ & $11788(80.0)$ & $1237(7.9)$ & $1099(7.1)$ & \\
\hline \multicolumn{11}{|c|}{ Interdental cleaning } \\
\hline No & $1558(6.3)$ & 19261(77.0) & $567(2.0)$ & $3617(14.6)$ & $<0.01$ & $1222(5.1)$ & $19095(80.0)$ & $1819(7.3)$ & $1856(7.6)$ & $<0.01$ \\
\hline Yes & $530(5.9)$ & $7163(78.6)$ & $255(2.6)$ & $1201(12.9)$ & & $441(5.6)$ & 6401(81.6) & $572(6.7)$ & $510(6.1)$ & \\
\hline \multicolumn{11}{|l|}{ Malodor } \\
\hline No & $1623(6.2)$ & $20855(78.2)$ & $629(2.2)$ & $3556(13.4)$ & $<0.01$ & $1355(5.4)$ & 20394(81.3) & $1776(6.6)$ & $1739(6.6)$ & $<0.01$ \\
\hline Yes & $465(6.4)$ & $5569(74.5)$ & $193(2.3)$ & $1262(16.8)$ & & $308(4.7)$ & $5102(76.9)$ & $615(9.1)$ & $627(9.4)$ & \\
\hline \multicolumn{11}{|l|}{ Fastfoods taking } \\
\hline$<3$ times/week & $1708(6.0)$ & $22296(77.2)$ & $726(2.3)$ & $4175(14.5)$ & $<0.01$ & $1419(5.2)$ & $22068(80.1)$ & $2121(7.3)$ & $2114(7.4)$ & $<0.01$ \\
\hline$\geq 3$ times/week & $380(7.7)$ & $4128(78.4)$ & $96(1.7)$ & $643(12.3)$ & & $244(5.9)$ & $3428(82.1)$ & $270(6.1)$ & $252(5.9)$ & \\
\hline \multicolumn{11}{|l|}{ Soda drinking } \\
\hline$<3$ times/week & $1310(6.0)$ & $17200(77.2)$ & $562(2.3)$ & $3202(14.5)$ & $<0.05$ & $1277(5.1)$ & $20264(80.4)$ & $1916(7.2)$ & $1916(7.4)$ & 0.61 \\
\hline$\geq 3$ times/week & $778(6.7)$ & $9224(77.8)$ & $260(2.0)$ & $1616(13.5)$ & & $386(5.8)$ & $5232(80.5)$ & $475(7.0)$ & $450(6.6)$ & \\
\hline \multicolumn{11}{|l|}{ Fruits taking } \\
\hline$<5$ times/week & $1389(6.1)$ & 17621(76.9) & $502(2.0)$ & $3422(15.0)$ & $<0.01$ & $1057(5.1)$ & $16566(79.5)$ & $1639(7.4)$ & $1741(8.0)$ & $<0.01$ \\
\hline$\geq 5$ times/week & $699(6.4)$ & $8803(78.4)$ & $320(2.6)$ & $1396(12.6)$ & & $606(5.6)$ & $8930(82.2)$ & $752(6.6)$ & $625(5.7)$ & \\
\hline
\end{tabular}

Values are presented as unweighted numbers (weighted \%).

P-value obtained from chi-square statistics.

비만율은 높게 조사되었다.

3. 성별에 따른 사회경제학적 변수와 전신건강요인과 구 취 자각률(Table 3)

전체 대상자 중에 구취 자각 경험이 있다고 응답한 대 상자는 $21.7 \%$ 이고 남학생에서 $22.2 \%$ 이며 여학생에서는 $21.0 \%$ 로 조사되었다. 구취 자각률은 중학생에서 $21.1 \%$ 이 며 고등학생에서 $23.2 \%$ 로 고등학생의 구취 자각률이 높았 으며 사회경제수준이 낮을수록, 부모의 학력수준이 낮을 수록, 학업성취도가 낮을수록, 운동량이 적을수록, 스트레 스 정도가 높을수록 구취 자각률이 높게 조사되었다.

4. 성별에 따른 구강건강행위와 음식섭취행위에 따른 구 취 자각률(Table 4)

일일 잇솔질 횟수가 3 회 미만이라고 응답한 $25.9 \%$ 에서 불쾌한 냄새를 경험하였다고 응답하였으며, 점심식사 후 잇솔질 실천율이 낮을수록, 패스트푸드 및 소다 식음수 섭 취횟수가 높을수록, 과일섭취가 적을수록 구취 자각률이 높게 조사되었다.

5. 회귀분석에 따른 비만율과 구취 자각률의 교차비 (Table 5)

과체중과 구취의 상관성을 분석하기 위해 전체 학생을 비만 및 구취 관련인자를 보정한 후 다변량 로지스틱 회
귀분석을 시행한 결과, 비만인 학생군에서 구취 자각률의 교차비가 1.22 로 조사되었고 성별로 나누어 분석한 결과 남학생의 경우 혼란변수를 모두 보정한 후에는 교차비가 1.15 로 조사되어 통계학적으로 유의하지 않았으나 여학생 의 경우 혼란변수를 모두 보정한 후에 교차비가 1.60 으로 증가하여 여학생에서 비만과 구취 자각률의 상관성이 증 가하였다(Table 4).

\section{고 찰}

청소년의 비만은 학업성취도뿐만 아니라 원활한 학교생 활과 전 생애에 걸쳐 건강에 부정적 영향을 미치며 구강 건강 악화와도 밀접한 관련성이 있기 때문에 청소년기에 서 체중관리가 중요한 관심사가 되고 있다[2, 5-7, 13, 14]. 구취는 구강건강과 밀접하게 연관되어 있으며[18] 청소년 기는 구취로 인하여 대인관계가 어려워질 수 있는 시기이 므로 구취관리가 중요하다[15]. 따라서 본 연구에서는 청 소년들을 대상으로 비만과 구취의 상관성을 조사하기 위 해 청소년들을 대상으로 비만과 구취 자각률을 조사하여 사회경제학적 변수 및 건강행위와 구강건강행태를 보정한 
Table 3. Perceived halitosis according to sociodemographic status and lifestyles by sex

\begin{tabular}{|c|c|c|c|c|c|c|c|c|c|}
\hline \multirow{3}{*}{ Variables } & \multicolumn{3}{|c|}{ Total, n (\%) } & \multicolumn{3}{|c|}{ Boys, n (\%) } & \multicolumn{3}{|c|}{ Girls, n (\%) } \\
\hline & \multicolumn{3}{|c|}{ Halitosis } & \multicolumn{3}{|c|}{ Halitosis } & \multicolumn{3}{|c|}{ Halitosis } \\
\hline & yes & no & $\mathrm{p}$-value & yes & no & $\mathrm{p}$-value & yes & no & $\mathrm{p}$-value \\
\hline Total & $14737(21.7)$ & $53306(78.3)$ & & $7825(22.2)$ & $27379(77.8)$ & & 6912(21.0) & $25927(79.0)$ & \\
\hline \multicolumn{10}{|l|}{ School type } \\
\hline Middle & $3766(21.1)$ & $14092(78.9)$ & $<0.01$ & $3332(20.1)$ & $13109(79.9)$ & $<0.01$ & 7098(20.6) & $27201(79.4)$ & $<0.01$ \\
\hline High & $4059(23.2)$ & $13287(76.8)$ & & $3580(21.9)$ & $12818(78.1)$ & & 7639(22.6) & $26105(77.4)$ & \\
\hline \multicolumn{10}{|l|}{ City scale } \\
\hline Big city & $3836(21.5)$ & $13935(78.5)$ & $<0.01$ & $3658(21.3)$ & $13443(78.7)$ & 0.203 & 7494(21.4) & $27378(78.6)$ & $<0.05$ \\
\hline Middle city & $3653(23.2)$ & $12151(76.8)$ & & 2934(20.9) & $11070(79.1)$ & & $6587(22.1)$ & 23221(77.9) & \\
\hline Town & $336(20.7)$ & 1293(79.3) & & $320(18.9)$ & 1414(81.1) & & $656(19.8)$ & 2707(80.2) & \\
\hline \multicolumn{10}{|c|}{ Perceived household economic status } \\
\hline High & 2498(18.6) & $11076(81.4)$ & $<0.01$ & 2017(18.3) & 8939(81.7) & $<0.01$ & $4515(18.5)$ & $20015(81.5)$ & $<0.01$ \\
\hline Low & $5327(24.5)$ & $16303(75.5)$ & & $4895(22.4)$ & $16988(77.6)$ & & $10222(23.5)$ & $33291(76.5)$ & \\
\hline \multicolumn{10}{|c|}{ Father's education (years) } \\
\hline$\geq 12$ & $3610(21.3)$ & $13370(78.7)$ & $<0.01$ & $3282(20.9)$ & $12389(79.1)$ & 0.515 & 6892(21.1) & $25759(78.9)$ & $<0.01$ \\
\hline $9-12$ & $4215(23.2)$ & $14009(76.8)$ & & $3630(21.2)$ & $13538(78.8)$ & & $7845(22.2)$ & $27547(77.8)$ & \\
\hline \multicolumn{10}{|c|}{ Mother's education (years) } \\
\hline$>12$ & $3222(21.5)$ & $11805(78.5)$ & $<0.01$ & $2864(20.7)$ & 10893(79.3) & 0.226 & $6086(21.1)$ & $22698(78.9)$ & $<0.01$ \\
\hline $9-12$ & $4603(22.8)$ & $15574(77.2)$ & & $4048(21.3)$ & $15034(78.7)$ & & $8651(22.1)$ & $30608(77.9)$ & \\
\hline \multicolumn{10}{|c|}{ Subjective academic achievement } \\
\hline High & 2781(20.9) & $10609(79.1)$ & $<0.01$ & $2598(21.2)$ & $9702(78.8)$ & 0.631 & $5379(21.0)$ & 20311(79.0) & $<0.01$ \\
\hline Low & $5044(23.1)$ & $16770(76.9)$ & & $434(21.0)$ & $16225(79.0)$ & & $9358(22.0)$ & $32995(78.0)$ & \\
\hline \multicolumn{10}{|l|}{ Drinking } \\
\hline No & $2155(23.5)$ & $6907(76.5)$ & 0.236 & $1672(23.5)$ & $5446(76.5)$ & 0.799 & $3827(23.5)$ & $12353(76.5)$ & 0.276 \\
\hline Yes & $1653(24.4)$ & $5157(75.6)$ & & $993(23.7)$ & $3200(76.3)$ & & $2646(24.1)$ & $8375(75.9)$ & \\
\hline \multicolumn{10}{|l|}{ Smoking } \\
\hline No & $1126(24.0)$ & $3513(76.0)$ & 0.236 & $485(25.9)$ & 1381(74.1) & 0.628 & $1611(24.5)$ & 4894(75.5) & 0.264 \\
\hline Yes & $1034(25.2)$ & $3065(74.8)$ & & $275(26.8)$ & $749(73.2)$ & & $1309(25.6)$ & $3814(74.4)$ & \\
\hline \multicolumn{10}{|l|}{ Physical activity } \\
\hline$<5$ times/week & $6400(23.0)$ & $21375(77.0)$ & $<0.01$ & $642(21.2)$ & $23897(78.8)$ & $<0.05$ & $12821(22.1)$ & $45272(77.9)$ & $<0.01$ \\
\hline$\geq 5$ times/week & $1425(19.3)$ & 6004(80.7) & & 491(19.2) & $2030(80.8)$ & & 1916(19.2) & 8034(80.8) & \\
\hline \multicolumn{10}{|l|}{ Stress } \\
\hline High & $3038(29.3)$ & 7247(70.7) & $<0.01$ & $3486(25.6)$ & $10187(74.4)$ & $<0.01$ & $6524(27.2)$ & $17434(72.8)$ & $<0.01$ \\
\hline Low & 4787(19.3) & $20132(80.7)$ & & $3426(17.8)$ & $15740(82.2)$ & & 8213(18.6) & $35872(81.4)$ & $<0.01$ \\
\hline
\end{tabular}

Values are presented as unweighted numbers (weighted \%).

$\mathrm{P}$-value obtained from chi-square statistics.

후 교차비를 분석한 결과 1.22 로 조사되었으며 성별로는 남성에서는 1.15 이었고 여성에서는 1.60 으로 여성의 경우 교차비가 증가하였다. 이러한 결과는 청소년들에서 구취 자각률과 비만율과의 상관성이 있음을 확인할 수 있었다.

비만에 영향을 미치는 사회경제학적 변수를 분석한 결과, 중학생 보다는 고등학생에서, 대도시보다는 중소도시 거주 자들에서, 경제수준이 낮을수록, 부모의 학력수준이 낮을수 록, 학업성적이 낮을수록 비만의 위험은 증가하였다(Table 1). 이러한 결과들은 비만과 사회경제학적 변수를 조사한 선행 연구들 $[2,19]$ 과 일치한다. 그리고 부모의 교육 수준이 낮을 수록 청소년 비만 위험률이 증가한 결과는, 최 등[20]의 연 구에서 발표한 바와 같이, 부모의 교육 정도가 높을수록 건
강에 대한 관심이 증가하여 식이와 운동에 대한 관심이 증 가한 결과 청소년의 건강행태에 긍정적인 영향력을 보였을 것으로 사료된다. 이러한 사회경제학적 변수는 비만뿐만 아니라 구취와도 밀접한 연관성이 있다고 보고한 바처럼 [15], 비만과 구취와의 연관성을 분석함에 있어서 이러한 공변수들을 보정함이 타당하다고 사료된다.

비만은 전신건강과 관련한 생활행태와도 밀접하게 연관 되어 있다고 보고되었는데[4] 이번 연구에서 비만 유병률 과 건강과 관련한 행태와의 상관성을 조사한 결과, 스트레 스가 높을수록, 운동량이 적을수록 비만율이 높게 조사되 었다. 스트레스는 구강건조를 유발하고 구강건조는 구취 유발과 밀접한 연관성이 있으므로[21] 구취는 스트레스와 
Table 4. Perceived halitosis according to oral health behaviors and food intake styles by sex

\begin{tabular}{|c|c|c|c|c|c|c|c|c|c|}
\hline \multirow{3}{*}{ Variables } & \multicolumn{3}{|c|}{ Total, n (\%) } & \multicolumn{3}{|c|}{ Boys, n (\%) } & \multicolumn{3}{|c|}{ Girls, n (\%) } \\
\hline & \multicolumn{3}{|c|}{ Halitosis } & \multicolumn{3}{|c|}{ Halitosis } & \multicolumn{3}{|c|}{ Halitosis } \\
\hline & yes & no & p-value & yes & no & p-value & yes & no & p-value \\
\hline \multicolumn{10}{|c|}{ Tooth brushing frequency } \\
\hline$<3$ times/day & $8784(25.9)$ & 24901(74.1) & $<0.01$ & $5124(25.8)$ & $14679(74.2)$ & $<0.01$ & $3660(26.1)$ & $10222(73.9)$ & $<0.01$ \\
\hline$\geq 3$ times/day & $5953(17.4)$ & $28405(82.6)$ & & $2701(17.6)$ & $12700(82.4)$ & & $3252(17.3)$ & $15705(82.7)$ & \\
\hline \multicolumn{10}{|c|}{ Toothbrushing after lunch } \\
\hline Mostly done & $5157(18.8)$ & $22379(81.2)$ & $<0.01$ & $22379(81.2)$ & $1895(19.1)$ & $<0.01$ & $3262(18.6)$ & $14215(81.4)$ & $<0.01$ \\
\hline Rare done & $9580(23.5)$ & $30927(76.5)$ & & $5930(23.4)$ & $19215(76.6)$ & & $3650(23.7)$ & $11712(76.3)$ & \\
\hline \multicolumn{10}{|c|}{ Interdental cleaning } \\
\hline No & $11035(21.9)$ & $39419(78.1)$ & 0.05 & $5791(22.5)$ & $19968(77.5)$ & 0.099 & $5244(21.2)$ & $19457(78.8)$ & $<0.01$ \\
\hline Yes & $3702(21.1)$ & $13887(78.9)$ & & $2034(21.5)$ & $7411(78.5)$ & & $1668(20.5)$ & $6476(79.5)$ & \\
\hline \multicolumn{10}{|l|}{ Fastfoods taking } \\
\hline$<3$ times/week & $12412(21.3)$ & $45762(78.7)$ & $<0.01$ & $6498(21.9)$ & $23199(78.1)$ & $<0.01$ & $5914(20.7)$ & $22563(79.3)$ & $<0.01$ \\
\hline$\geq 3$ times/week & $2325(23.6)$ & $7544(76.4)$ & & $1327(24.0)$ & $4180(76.0)$ & & $998(22.9)$ & $3364(77.1)$ & \\
\hline \multicolumn{10}{|l|}{ Soda drinking } \\
\hline$<3$ times/week & $10304(21.1)$ & $38588(78.9)$ & $<0.01$ & $4921(21.5)$ & $17966(78.5)$ & $<0.01$ & $5383(20.7)$ & $20622(79.3)$ & $<0.01$ \\
\hline$\geq 3$ times/week & $4433(23.2)$ & $14718(76.8)$ & & $2904(23.5)$ & $9413(76.5)$ & & $1529(22.4)$ & $5305(77.6)$ & \\
\hline \multicolumn{10}{|l|}{ Fruits taking } \\
\hline$<5$ times/week & $10287(22.7)$ & $35024(77.3)$ & $<0.01$ & $5573(23.5)$ & $18097(76.5)$ & $<0.01$ & $4714(21.8)$ & $16927(78.2)$ & $<0.01$ \\
\hline$\geq 5$ times/week & $4450(19.6)$ & $18282(80.4)$ & & $2252(19.6)$ & $9282(80.4)$ & & $2198(19.6)$ & $9000(80.4)$ & \\
\hline
\end{tabular}

Values are presented as unweighted numbers (weighted \%).

P-value obtained from chi-square stastistics.

Table 5. Odds ratios of subjective perceived halitosis for obesity in the series of adjusted models

\begin{tabular}{|c|c|c|c|c|}
\hline Model & & Model 1 & Model 2 & Model 3 \\
\hline \multirow[t]{3}{*}{ Total } & Reference & 1 & 1 & 1 \\
\hline & Overweight & $1.38(1.26-1.51) \dagger$ & $1.37(1.26-1.50) \dagger$ & $1.26(0.91-1.75)$ \\
\hline & Obesity & $1.35(1.27-1.44) \dagger$ & $1.35(1.27-1.44) \dagger$ & $1.22(1.06-1.45)$ \\
\hline \multicolumn{5}{|l|}{ Sex } \\
\hline \multirow[t]{3}{*}{ Boys } & Reference & 1 & 1 & 1 \\
\hline & Overweight & $1.16(0.98-1.38)$ & $1.19(1.10-1.41)$ & $1.11(0.61-2.00)$ \\
\hline & Obesity & $1.29(1.20-1.39)$ & $1.29(1.20-1.40)$ & $1.15(0.98-1.35)$ \\
\hline \multirow[t]{3}{*}{ Girls } & Reference & 1 & 1 & 1 \\
\hline & Overweight & $1.47(1.33-1.63)$ & $1.47(1.32-1.62)$ & $1.38(0.92-2.06)$ \\
\hline & Obesity & $1.44(1.33-1.64)$ & $1.48(1.33-1.64)$ & $1.60(1.17-2.20)$ \\
\hline
\end{tabular}

Model 1 Adjusted for sex (only in $\dagger$ ), school type, city scale.

Model 2 Adjusted for sex (only in $\dagger$ ), school type, city scale, economic status, parents' education levels.

Model 3 Adjusted for sex (only in $\dagger$ ), school type, city scale, economic status, parents' education levels, academic achievement, stress, physical activity, taking of fastfood, soda, and fruits, tooth brushing frequency, and interdental cleaning.

Bold denotes statistical significance at $\mathrm{p}<0.05$.

밀접하게 연관되어 있다고 생각되며, 과일섭취는 구강 내 자정작용의 증가로 구취를 유발할 치면세균막의 양을 감 소시키거나 구취유발 휘발성 황 화합물의 양을 감소시켜 구취를 약화시킬 수 있다고 사료된다[15]. 그리고 식이습 관과 비만율을 비교한 결과, 패스트푸드를 적게 먹을수록, 탄산음료를 적게 먹을수록, 과일섭취량이 적을수록 비만 위험률이 증가하였다(Table 2). 패스트푸드와 탄산음료 등 은 청소년의 비만을 유발할 수 있는 대표적인 음식으로 간
주되어 섭취를 제한하도록 강조하고 있음에도 불구하고 [19] 이번 청소년 온라인행태조사에서는 패스트푸드와 탄 산음료를 적게 섭취하는 청소년에서 비만율이 높게 조사 되었다. 이러한 결과는 비만한 청소년들이 체중감량을 위 해 식사량을 조절하는 것과 마찬가지로 패스트푸드와 탄 산음료를 조절한다고 생각할 수도 있으며, 일부 비만한 사 람의 경우 섭취한 식품의 양을 과소 보고하는 경향이 강 하기 때문에 나타난 현상일 수도 있고[22] 설문조사만으로 
는 패스트푸드나 탄산음료의 양을 정확하게 평가하는 데 어렵기 때문일 수 있다.

비만율은 칫솔질 횟수가 적고 점심식사 후 칫솔질을 수 행하지 않을수록 높게 조사되었는데(Table 3), 비만인 청 소년들은 자신의 구강건강관리를 소홀하게 관리한다고 보 고한 선행 연구와 일치한다[23]. 동시에 이러한 잇솔질 및 구강관리용품 등을 이용한 구강건강행위는 구취에도 영향 을 미친다고 보고되었는데[24], 비만군은 전반적으로 구강 건강에 관한 관심이 적어 구강건강행위인 잇솔질의 횟수 도 정상 체중군에 비해 적을 것이라 설명할 수 있으며 동 시에 이러한 구강관리행위는 구취 유발에도 영향을 미친 다고 사료된다. 따라서 비만율과 구취 여부의 연관성을 확 인하기 위해 이러한 공통의 구강건강행위 변수들을 보정 함이 타당하다고 사료된다.

구취 자각률은 중학생 보다는 고등학생에서, 대도시보 다는 중소도시에서, 가족경제수준이 낮을수록, 부모 학력 수준이 낮을수록, 운동량이 적을수록, 스트레스가 많을수 록 높게 조사되었다. 이러한 경향은 김 등[15]의 연구와 비 슷한 결과를 보였다. 그러므로 비만과 구취에 영향을 미치 는 공통인자를 관리하는 것은 구취예방과 비만 예방에 효 과적이라고 사료된다. 반면 여학생의 경우 학업성취도가 낮을수록 구취 자각률이 높았으나 남학생의 경우는 상관 성을 보이진 않았다. 이러한 차이는 여성이 남성에 비해 사회 경제적 환경에 민감한 영향을 받으며, 그러한 영향이 본인의 건강관리에 부정적으로 영향을 미친다고 보고한 결과와 일치한다[25].

구취 자각률은 잇솔질 횟수가 적을수록, 그리고 점심식 사 후 잇솔질을 시행하지 않을수록 더 높게 조사되었는데 이러한 경향성은 선행연구 결과와 일치하며[26], 구취의 일차적인 원인이 구강내 치면세균막과 설태임을 고려할 때 잇솔질 횟수는 구취 예방에 중요한 요인임을 강조할 수 있다. 그리고 구취 자각률은 패스트푸드 음식이나 소다 식 음료 섭취횟수가 많을수록, 그리고 과일섭취 횟수가 적을 수록 더 높게 관찰되었다(Table 4). 이러한 결과는 김 등 [15]의 연구와 비슷하며 향 후 구취예방사업을 추진함에 있어서 청소년들의 식이관리와 병행하면 구취예방사업이 더 효율적으로 관리될 수 있다고 사료된다.

사회가 발전함에 따라 남자보다는 여자가 비만에 대해 더욱 부정적인 인식을 갖는다고 하였으며 [27] 남자의 경우 소득의 증대와 건강한 생활과의 연관성이 낮은 반면 여성 의 경우 건강에 대한 민감도가 높게 보고되어[28] 비만에 관한 조사결과는 성별로 나누어 분석함이 타당하다고 사 료된다. 본 연구에서도 남녀로 나누어 분석한 결과, 여학 생에서는 구취 자각률과 비만율의 연관성을 분석한 결과 모든 변수를 보정한 후 교차비가 1.60 로 조사된 반면 남성 의 경우는 교차비가 1.15 로 통계적인 유의성이 관찰되지
않았다. 우리나라 청소년들에 있어서는 구취 자각률과 비 만과의 연관성이 남성보다는 여성에서 조금 더 높음을 알 수 있는데 이러한 결과는 향 후 청소년 건강관리사업을 설 계함에 있어서 성별로 나누어 구강보건사업을 설계하는 것에 대한 시사점이 있다고 사료된다.

비만과 구취의 연관성에 관한 인과관계를 입증하기 위 해서는 본 논문에서 조사한 구취자각을 병적 구취의 설문 내용까지 포함하여 조사해야 할 뿐만 아니라 실험실 연구 및 대규모 집단을 대상으로 하는 전향연구와 구취에 영향 을 미치는 다양한 구강 내 세균 및 구강 내 염증성 질환 을 동시에 분석함이 타당하다고 사료된다.

구취 자각과 비만과의 연관성을 보고한 선행연구와[15] 본 연구를 종합하여 고려할 때, 구취와 비만을 예방하고 관리하는 보건사업이 중요하며 이러한 건강증진사업들은 비만과 구강건강을 분리하여 관리하는 것이 아닌 통합적 인 건강증진프로그램으로 설계함이 타당하며 국가차원에 서 사업을 기획하고 지방자치단체 단위의 보건소에서 사 업을 수행하고 관리하여야 한다고 사료된다. 동시에, 이러 한 통합건강증진사업은 비만자들에게 건강관리의 중요성 을 인지시키고, 행동으로 실천할 수 있도록 용이한 실천방 향을 제시할 뿐만 아니라 구강건강과의 연관성을 파악하 여 구강건강증진을 위한 구강보건교육을 동시에 수행할 수 있는 전문인력의 양성도 요구된다.

본 연구의 제한점은 청소년건강행태 온라인 조사가 단면 연구이기 때문에 구취 자각과 관련된 요인과의 인과관계를 설명하기 어려우며, 조사대상자가 주관적으로 느낀 구취자 각 유무만을 파악하여 구취에 대한 정확한 측정이 이루어 지지 않았다는 점이다. 그러나 구취 자각은 객관적 도구를 이용한 구취와 강한 상관관계를 보인다는 연구결과를 토대 로[26], 본 연구에서 사용한 구취 자각정도가 객관적 구취 와의 연관성이 있다고 조심스럽게 제시할 수 있다고 생각 된다. 그리고 신장과 체중을 본인이 입력하는 방식을 사용 하여 비만이 저평가되었을 가능성이 있으며, 사회경제학적 변수들이 청소년이 보고한 것이므로 부정확할 가능성이 있 다. 향 후 연구에서는 비만과 구취를 포함하여 구강질환의 전반적인 연관성에 대하여 공통 위험요인과 함께 분석함이 타당하다고 사료되며 보다 잘 고안된 전향연구를 통해 관 련요인에 대한 분석이 필요할 것으로 사료된다.

우리나라 청소년을 대상으로 청소년들의 구취자각 실태 및 비만율의 상관관계를 파악하여 구취 예방 및 비만 예 방을 위한 기초 자료로 활용하기 위하여 2015년 청소년건 강행태온라인조사의 자료를 토대로 상관성을 분석한 결과 
다음과 같은 결론을 얻었다.

1. 우리나라 청소년들 중 남학생들의 $2.2 \%$ 에서 과체중 으로 조사되었고 $14.2 \%$ 에서 비만으로 조사되었으며 여학 생들의 $7.1 \%$ 에서 과체중으로 조사되었고 $7.2 \%$ 에서 비만 으로 조사되었다. 비만율은 중학생보다는 고등학생에서, 거주지역이 도시지역보다는 군지역에서, 부모의 사회경제 적 수준이 낮을수록, 부모의 학력수준이 낮을수록, 학업성 취도가 낮을수록, 운동량이 적을수록, 스트레스 정도가 심 할수록 높게 조사되었다. 그리고 하루 잇솔질 횟수가 적을 수록, 점심 후 잇솔질을 하지 않을수록, 구강관리용품을 이용한 치간세정을 하지 않을수록, 과일 섭취량이 적을수 록 비만율은 높게 조사되었다.

2. 구취 자각률은 중학생보다는 고등학생에서, 사회경제 수준이 낮을수록, 부모의 학력수준이 낮을수록, 학업성취 도가 낮을수록, 운동량이 적을수록, 스트레스 정도가 높을 수록 높게 조사되었다. 그리고 일일 잇솔질 횟수가 적을수 록, 점심식사 후 잇솔질 실천율이 낮을수록, 패스트푸드 및 소다 식음료 섭취횟수가 높을수록, 그리고 과일섭취가 적을수록 높게 조사되었다.

3. 청소년들의 비만과 구취 자각률의 상관성을 분석하기 위해 여러 사회경제학적 변수 및 건강관련 행태를 보정하 여 로지스틱 회귀분석으로 분석한 결과 교차비가 1.22 로 조사되었으며 성별로 분류하여 분석하였을 때 남성의 경 우는 상관성이 관찰되지 않은 반면, 여성의 경우는 1.60 배 로 교차비가 증가하였다.

이러한 결과는 향 후 건강증진사업들을 계획함에 있어 서 비만과 구강건강을 통합하여 관리하여야 함을 시사하 며 향 후 국가차원의 건강증진사업이나 개별 보건소 중심 의 보건사업을 설계함에 있어서 기초자료로 활용될 수 있 을 것으로 기대한다.

\section{감사의 글}

이 논문은 2018학년도 백석대학교 대학연구비에 의하여 수행되었음.

\section{Conflict of Interest}

The authors declare that they have no competing interests.

\section{ORCID}

Seon-Ju Sim 0000-0002-6360-187X

\section{References}

1. Suchindran C, North KE, Popkin BM, Gordon-Larsen P. Association of adolescent obesity with risk of severe obesity in adulthood. JAMA 2010;304:2042-2047. doi: 10.1001/jama.2010.1635.

2. Choi SW, Park DJ, Kim J, Park TJ, Kim JS, Byun S, Lee YS, Kim JH. Association between obesity and neighborhood socioeconomic status in Korean adolescents based on the 2013 Korea youth risk behavior web-based survey. Korean J Fam Med 2016;37:64-70. doi: 10.4082/ kjfm.2016.37.1.64.

3. Doll S, Paccaud F, Bovet P, Burnier M, Wietlisbach V. Body mass index, abdominal adiposity and blood pressure: consistency of their association across developing and developed countries. Int J Obes Relat Metab Disord 2002;26:48-57. doi: 10.1038/ sj.ijo.0801854.

4. Lioret S, Maire B, Volatier J, Charles M. Child overweight in France and its relationship with physical activity, sedentary behaviour and socioeconomic status. Eur J Clin Nutr 2007;61:509-516. doi: 10.1038/sj.ejcn.1602538.

5. Adami F, Vasconcelos Fde A. Childhood and adolescent obesity and adult mortality: a systematic review of cohort studies. Cad Saude Publica 2008;24:s558-s568. doi: 10.1590/S0102-311X2008001600008.

6. McElroy SL, Kotwal R, Malhotra S, Nelson EB, Keck $\mathrm{PE}$, Nemeroff $\mathrm{CB}$. Are mood disorders and obesity related? A review for the mental health professional. J Clin Psychiatry 2004;65:634-651.

7. Hsu CY, Bates DW, Kuperman GJ, Curhan GC. Diabetes, hemoglobin A(1c), cholesterol, and the risk of moderate chronic renal insufficiency in an ambulatory population. Am J Kidney Dis 2000;36:272-281. doi: 10.1053/ajkd.2000.8971.

8. Eli I, Baht R, Koriat H, Rosenberg M. Self-perception of breath odor. J Am Dent Assoc 2001;132:621-626. doi: 10.14219/jada.archive.2001.0239.

9. Shin SC, Lee KS. An epidemiological study on malodor status in Korean people. J Korean Acad Dent Health 1999;23:343-359.

10. Yu M, Goo K, Kim J. A study on the oral health behavior of high school students in Jeolla-bukdo. J Dent Hyg Sci 2009;9:225-230.

11. Gungor NK. Overweight and obesity in children and adolescents. J Clin Res Pediatr Endocrinol 2014;6:129143. doi: $10.4274 /$ jcrpe. 1471.

12. Sheiham A, Watt RG. The common risk factor approach: a rational basis for promoting oral health. Community Dent Oral Epidemiol 2000;28:399-406.

13. Al-Zahrani MS, Bissada NF, Borawski EA. Obesity and periodontal disease in young, middle-aged, and older adults. J Periodontol 2003;74:610-615. doi: 10.1902/jop. 
2003.74.5.610.

14. Hilgers KK, Kinane DE, Scheetz JP. Association between childhood obesity and smooth-surface caries in posterior teeth: a preliminary study. Pediatr Dent 2006;28:23-28.

15. Kim SY, Sim S, Kim SG, Park B, Choi HG. Prevalence and associated factors of subjective halitosis in Korean adolescents. PLoS One 2015;10:e140214. doi: 10.1371/ journal.pone.0140214.

16. Korea centers for disease control and prevention. 2015 Korean youth's risk behaviors web-based survey (KYRBWS) [Internet]. Cheongju: Korea centers for disease control and prevention; 2016 [cited 2016 Dec 13]. Available from: http://yhs.cdc.go.kr.

17. Korea center for disease control and prevention, The Korean pediatric society. 2007 Korean children and adolescents growth standards[Internet] Seoul: Korea centers for disease control and prevention 2016 [cited 2016 Dec 20]. Available from http://www.cdc.go.kr.

18. Lu HX, Chen XL, Wong M, Zhu C, Ye W. Oral health impact of halitosis in Chinese adults. Int J Dent Hyg 2017;15:e85-e92. doi: 10.1111/idh.12242.

19. Yoon YS, Oh SW, Park HS. Socioeconomic status in relation to obesity and abdominal obesity in Korean adults: a focus on sex differences. Obesity (Silver Spring) 2006;14: 909-919. doi: 10.1038/oby.2006.105.

20. Choi BY, Lee DC, Chun EH, Lee JY. The relationship between metabolic syndrome and childhood maternal education level, job status findings from the Korean national health and nutrition examination, 2007-2009. Korean J Fam Med 2014;35:207-215. doi: 10.4082/ kjfm.2014.35.4.207.
21. Kurihara E, Marcondes FK. Oral concentration of volatile sulphur compounds in stressed rats. Stress 2002;5: 295-298. doi: 10.1080/1025389021000061192.

22. Goris AH, Westerterp-Plantenga MS, Westerterp KR. Undereating and underrecording of habitual food intake in obese men: selective underreporting of fat intake. Am J Clin Nutr 2000;71:130-134.

23. Ostberg AL, Bengtsson C, Lissner L, Hakeberg M. Oral health and obesity indicators. BMC Oral Health 2012; 12:50. doi: 10.1186/1472-6831-12-50.

24. Seemann R, Conceicao MD, Filippi A, Greenman J, Lenton P, Nachnani S, Quirynen M, Roldan S, Schulze H, Sterer N, Tangerman A, Winkel EG, Yaegaki K, Rosenberg M. Halitosis management by the general dental practitioner-results of an international consensus workshop. J Breath Res 2014;8:017101. doi: 10.1088/ 1752-7155/8/1/017101.

25. Sorlie PD, Backlund E, Keller JB. US mortality by economic, demographic, and social characteristics: the National Longitudinal Mortality Study. Am J Public Health 1995;85:949-956.

26. Rosenberg M. Clinical assessment of bad breath: current concepts. J Am Dent Assoc 1996;127:475-482. doi: 10.14219/jada.archive.1996.0239.

27. Wardle J, Griffith J. Socioeconomic status and weight control practices in British adults. J Epidemiol Community Health 2001;55:185-190. doi: 10.1136/ jech.55.3.185.

28. Zhang Q, Wang Y. Socioeconomic inequality of obesity in the United States: do gender, age, and ethnicity matter? Soc Sci Med 2004;58:1171-1180. doi: 10.1016/ S0277-9536(03)00288-0. 